
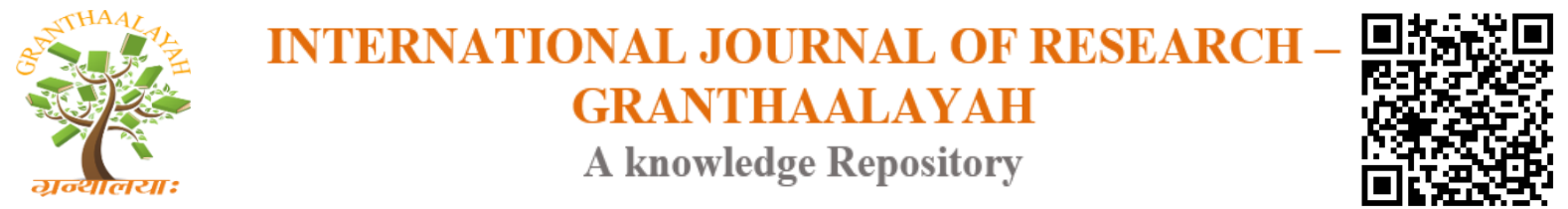

Social

\title{
QUANTITATIVE APTITUDE AMONG HIGHER SECONDARY STUDENTS
}

\author{
Mrs. P.Kanimozhi ${ }^{1}$, Dr.P.Ganesan ${ }^{2}$ \\ ${ }^{1}$ Research Scholar (Part-Time), Tamil Nadu Teachers Education University, Karapakkam, \\ Chennai- 600 097, India \\ ${ }^{2}$ Professor and Head, Department of Pedagogical Science, Tamil Nadu Teachers Education \\ University, Karapakkam, Chennai-600 097, India
}

DOI: https://doi.org/10.29121/granthaalayah.v5.i5(SE).2017.1977

\begin{abstract}
The present study is a survey in nature to find out quantitative aptitude among higher secondary students in Madurai District. The investigator in order to find out quantitative aptitude among higher secondary students developed and validated a tool for the study. The investigator followed stratified random sampling method for the study. Data were collected from the sample. The data were given appropriate statistical treatments. The findings of the study reveal that the majority of higher secondary students $(54.22 \%)$ are at average level of quantitative aptitude. In differential analysis, there is significant difference in level of quantitative aptitude among higher secondary students in terms of sex. The male students are having more level of quantitative aptitude compared to their counterparts. But there seems to be no significant difference in quantitative aptitude among higher secondary students in terms of locality.
\end{abstract}

Keywords: Quantitative; Aptitude; Higher Secondary Students.

Cite This Article: Mrs. P.Kanimozhi, and Dr.P.Ganesan. (2017). "QUANTITATIVE APTITUDE AMONG HIGHER SECONDARY STUDENTS." International Journal of Research - Granthaalayah, 5(5)SE, 93-97. 10.29121/granthaalayah.v5.i5(SE).2017.1977.

\section{Introduction}

An aptitude is an innate component of a competency to do a certain kind of work at a certain level. Aptitudes may be physical or mental. The innate nature of aptitude is in contrast to achievement, which represents knowledge or ability that is gained.

Quantitative aptitude is the ability to do numerical calculations. It refers to the physical and psychological disposition of students towards numerical values and its manipulations. The competitive examinations are having quantitative aptitude test. Especially in Banking Service examinations, the quantitative aptitude tests are being used to test the students' numerical ability. 
The speed and the rate at which the students finish mathematical calculations and other similar mathematical operations are very much essential for banking sector. In these examinations there has been considerable number of failures from our Tamil Nadu. The study of mathematics subject will improve quantitative aptitude of higher secondary students. Every year a large number of higher secondary students get centum score in mathematics. The investigator being a mathematics teacher and researcher in the field of Education thought of the conduct of present study.

\section{Objectives of the Study}

1) To study the level of quantitative aptitude among higher secondary students.

2) To find out the significant difference in level of quantitative aptitude among higher secondary students in terms of sex.

3) To find out the level of quantitative aptitude among higher secondary students in terms of locality.

\section{Hypotheses}

1) The level of quantitative aptitude among higher secondary students is average.

2) There is no significant difference in level of quantitative aptitude among higher secondary students in terms of sex.

3) There is no significant difference in level of quantitative aptitude among higher secondary students in terms of locality.

\section{Terms and Definitions}

- Quantitative Aptitude - refers to numerical and mathematical ability of students or disposition towards numerical ability both physically and mentally.

- Higher Secondary Students - refers to the students at $11^{\text {th }}$ and $12^{\text {th }}$ std.

\section{Delimitations and Scope of the Study}

The study is confined only to higher secondary students in Madurai only. The subgroups identified for the study were sex and locality.

The finding of the study will reveal the level of quantitative aptitude among higher secondary students in Madurai only. It cannot be over generalized and considered as an overall reflection of level of quantitative aptitude among higher secondary students in other cities. However it may give an idea about level of quantitative aptitude among higher secondary students.

\section{Planning of the Multiple Choice Items}

The researcher studied the concept of quantitative aptitude in detail and decided to have 50 items. Each item has 4 alternate answers. The candidate has to choose any one item. The items are of multiple choice types. 


\section{Establishing Reliability of the Tool}

\subsection{Test and Retest Method}

The test was administered among the 20 students and re-administered among the same 20 after of 15 days. The comparative performance and deviation were analyzed. The deviation is negligible. Hence the tool is assumed to be having reliability. Thus the reliability was ensuring the tryout.

\subsection{Establishing Validity of the Tool}

The face and content validity was established for this tool. The face and content validity was checked with Mathematics teachers in the Thigarajar Model Higher Secondary school and Sourashtra Girls higher Secondary school. The concurrent validity was checked by repeated administration of the tool. According to Garret, H.E (1967, P.365) the index of reliability is also taken as a measure of validity.

\subsection{Scoring}

The tool consists of 50 multiple choice items. Each item will get I mark. The total marks will be 50 .

\subsection{Sample}

The investigator has followed stratified random sampling method for the Present study. There were 201 students taken for the study. The strata were Government, Government- Aided and Self-Finance higher secondary schools in Madurai.

\section{Analysis and Interpretation of Data}

\section{HYPOTHESIS: 1}

The level of quantitative aptitude among higher secondary students is average.

Table 1: Percentage Analysis for the Level of Quantitative Aptitude among Higher Secondary Students

\begin{tabular}{|l|l|l|}
\hline Description & No of students & Percentage \\
\hline High & 80 & 39.80 \\
\hline Average & 109 & 54.22 \\
\hline Low & 12 & 5.97 \\
\hline
\end{tabular}

It is evident from Table 4.1 that the higher secondary students who have high level of quantitative aptitude are 80 students out of 201 students forming 39.80 percentage. The students who have average level of quantitative aptitude are 109 out of 201 students in the sample covering a percentage of 54.22. The students at the bottom level are 12 with a percentage of 5.97 . 
It may be concluded from the above that the majority of higher secondary students are at average level of quantitative aptitude. But it is heartening to note that the higher secondary students covering about 40 percentages are having high level of quantitative aptitude. It is further noticed that the only 5.97 percentage of higher secondary students (single digit percentage) only have low level of quantitative aptitude.

\section{HYPOTHESIS: 2}

There is no significant difference in level of quantitative aptitude among higher secondary students in terms of sex.

Table 2: Mean, S.D. 'T' Values for the Level of Quantitative Aptitude among Higher Secondary Students in Terms of Sex.

\begin{tabular}{|l|l|l|l|l|l|l|}
\hline Sex & N & Mean & SD & $\begin{array}{l}\text { 't' } \\
\text { Value }\end{array}$ & Critical Value & $\begin{array}{l}\text { Level of } \\
\text { Significance }\end{array}$ \\
\hline Male & 113 & 47.66 & 8.91 & 7.01382 & $\begin{array}{l}1.960 \text { for degree } \\
\text { of freedom of 199 } \\
\text { at } 0.05 \text { level }\end{array}$ & $\begin{array}{l}\text { No } \\
\text { Significance }\end{array}$ \\
\hline Female & 88 & 40.05 & 6.72 & & \\
\hline
\end{tabular}

It is evident from table 2 that the obtained ' $t$ ' value is 7.01382. It is more than the critical value of 1.960 for degrees of freedom of 199 at 0.05 level. Hence, it is significant. The male students (47.66) are having level of quantitative aptitude more than female students (40.05). The hypothesis stated as there is no significant difference in level of quantitative aptitude among higher secondary students in terms of sex is rejected.

It may be concluded from the above table that there is significant difference in level of quantitative aptitude among higher secondary students in terms of sex. The male students are having more level of quantitative aptitude compared to their counterparts.

\section{HYPOTHESIS: 3}

There is no significant difference in level of quantitative aptitude among higher secondary students in terms of locality.

Table 3: Mean, S.D. 'T' Values in Level of Quantitative Aptitude among Higher Secondary Students in Terms of Locality.

\begin{tabular}{|l|l|l|l|l|l|l|}
\hline Locality & $\mathbf{N}$ & Mean & SD & 't' Value & Critical Value & $\begin{array}{l}\text { Level of } \\
\text { Significance }\end{array}$ \\
\hline Rural & 66 & 43.65 & 8.58 & \multirow{2}{*}{0.439986} & $\begin{array}{l}1.960 \text { for degree } \\
\text { of freedom of } \\
199 \text { at } 0.05 \text { level }\end{array}$ & $\begin{array}{l}\text { No } \\
\text { Significance }\end{array}$ \\
\hline Urban & 135 & 44.66 & 9.00 & & \\
\hline
\end{tabular}

It is evident from table 3 that the obtained ' $t$ ' value is 0.439986 . It is less than the critical value of 1.960 for degrees of freedom of 199 at 0.05 level. Hence, it is not significant. The hypothesis 
stated as there is no significant difference in level of quantitative aptitude among higher secondary students in terms of locality is accepted.

It may be concluded from the above table that there is no significant difference in level of quantitative aptitude among higher secondary students in terms of locality.

\section{Findings of the Study}

The following are the findings of the study:

1) The majority of higher secondary students (54.22\%) are at average level of quantitative aptitude. But it is heartening to note that the next major chunk of higher secondary students (39.40 percentages) is having high level of quantitative aptitude. It is further noticed that the only 5.97 percentage of higher secondary students (single digit percentage) only have low level of quantitative aptitude.

2) There is significant difference in level of quantitative aptitude among higher secondary students in terms of sex. The male students are having more level of quantitative aptitude compared to their counterparts.

3) There is no significant difference in level of quantitative aptitude among higher secondary students in terms of locality.

\section{References}

[1] Best, J.W., Research in Education, New Delhi, Prentice Hall of India, 1977

[2] Buch, M.N., Fourth Survey of Research in Education, New Delhi, NCERT, 1991

[3] Golden, S. A. R. (2011). Problems and Prospectus of Distance Education. Quality Enhancement In Distance Education For Life Long Learning, 1(1), 343-344.

[4] Golden, S. A. R. (2016). RURAL STUDENTS' ATTITUDE TOWARDS ENGLISH AS MEDIUM OF INSTRUCTION IN HIGHER EDUCATION - AN ANALYSIS. International Journal of Research, 3(Special Issue - 16), 1-10.

[5] Golden, S. A. R. (2017). Attitude of Students and Teachers towards E- Learning - An Analysis. Recent Research in Social Science \& Humanities, 1, 5-10.

[6] Golden, S. A. R. (2017). Recent Research In Social Science \& Humanities.

[7] Good, C.V., Dictionary of Education, New York, MC Graw Hill Book Company, 1959

[8] Grewal, P.S. Method of Statistical Analysis, New Delhi, Sterling Publishers Private Limited, 1990.

[9] Kochher, K.S. Pivotal Issues in Indian Education, New Delhi, Sterling Publishers Private Ltd., 1981

[10] Malhotra, Deepak. "The Desire to Win: The Effects of Competitive Arousal on Motivation and Behavior." Organizational Behavior and Human Decision Processes 111 (2010): 139-146

[11] Regi, S. B., \& Golden, S. A. R. (2014). A DESCRIPTIVE STUDY ON THE ROLE OF CONSUMER PSYCHOLOGY AND BEHAVIOUR IN PRODUCT PURCHASING”. Indian Streams Research Journal, 3(12), 1-6.

[12] The Oxford Dictionary of English Etymology, 1983 reprint. ISBN 0-19-861112-9. 